\title{
Negotiating the Minefields of Corporate Vote-Buying
}

\section{Luh Luh Lan* and Loizos Heracleous}

Corporate vote-buying has received significant attention in the last decade, in several legal cases that illustrate the fine line between legitimate use of vote harnessing as a useful corporate strategic tool on one hand, and its negative connotations as a potential instrument of fraud that attempts to disfranchise shareholders on the other hand. After a brief outline of the legal history of corporate vote-buying and the rationale for the courts' vigilance on this practice, in both the United States and the United Kingdom, we outline some strategic reasons for votebuying that might make it a useful option in certain circumstances. Lastly we discuss key principles that a board of directors should bear in mind when engaging in corporate votebuying, so that it can employ the practice productively and legitimately, keeping in mind shareholders' best interests and avoiding potentially costly and destructive legal challenges.

Keywords: Corporate governance, corporate vote-buying, United States, United Kingdom, company law

\section{Introduction}

T here was a lot at stake in the battle between the pro-merger and the dissident groups of the HP-Compaq merger. Not just the US $\$ 18.9$ bn deal itself, but also the traditional $\mathrm{HP}$ way according to the dissidents, significant restructuring at HP, as well as Carly Fiorina's job. If Fiorina failed, the dissidents, which included Walter Hewlett, the son of the company co-founder William Hewlett and the sole HP director at that time to oppose the deal, David W. Packard, the son of the other co-founder, together with the staunch supporters of the old HP way, were unlikely to let her stay after the expensive and ugly proxy battle. Then there was the high-drama law suit where HP management was accused of having lied to shareholders about their financial projections; and to have bought votes from a key investor on the eve of the merger vote so that they could push through approval of the merger.

The vote result was less than 1 per cent in favour of the pro-merger group; the crucial difference was made by the $17 \mathrm{~m}$ DeutscheBank votes, which management allegedly bought from the bank, under threat of severing further business ties with it. Carly Fiorina and the pro-merger group emerged victorious, both in the shareholders merger vote as well as the lawsuit. Hewlett was ousted from the HP board, leaving the company without a member of the Hewlett or Packard families on its board for the first time in its 63 year history.

The decision of the Delaware Chancery Court ${ }^{1}$ was pivotal. Although Fiorina and her board eventually won at the trial, round one was awarded to Hewlett, who brought the action against the company contesting the validity of the shareholder vote ${ }^{2}$ after failing to garner enough support to oppose the merger. The defendants' motion to dismiss Hewlett's claim was denied by the court. During the motion hearing, the judge addressed the alleged vote-buying that took place between Deutsche Bank and the HP management, laying down important guidelines which have important implications for senior managers and boards of directors contemplating votebuying to support their strategic decisions.

Legal cases such as the above have raised interest in corporate vote-buying and highlight the fine line between its legitimate use as
*Address for correspondence: NUS Business School, National University of Singapore, 1 Business Link, Singapore 117592. Tel: +65 6516 3099; E-mail: bizlanll@nus.edu.sg 
a useful corporate strategic tool on one hand, and its negative connotations as a potential instrument of fraud that could disfranchise shareholders on the other hand. In this paper we outline the legal history of corporate votebuying and the rationale for the courts' vigilance on this practice, in both the United States and the United Kingdom. We then outline some strategic reasons for vote-buying that might make it a useful option in certain circumstances. Lastly we discuss key principles that a board of directors should bear in mind when contemplating whether to engage in corporate vote-buying, so that it can employ the practice productively and legitimately, keeping in mind shareholders' best interests and avoiding potentially costly and destructive legal challenges.

Vote-buying has unfavourable connotations, and is certainly illegal in the political arena. We propose, however, that in the corporate arena it can be a useful and legitimate tool for garnering support for strategic actions that management believes are in the best interests of the company and the shareholders. Why is the seemingly distasteful action of vote-buying perfectly legitimate in the corporate arena? How can managers and boards engage in votebuying legitimately and in shareholders' best interests without attracting legal liability? What are the minefields that should be avoided? As far as we are aware these questions have not been addressed adequately and in a manner relevant to the concerns of company directors in the corporate governance literature, and this paper aims to fill this gap.

\section{The legal basis of vote-buying in US corporations}

Although the buying of votes in a political election is illegal in US federal and state elections (Hasen, 2000), in the corporate context, vote-buying is simply seen as an agreement where stockholders give up their voting powers to the buyer, in return for a consideration paid to the stockholders (Schreiber $v$. Carney). The consideration can range from cash offer (Kass v. Eastern Airlines), a loan (Schreiber's case), or the granting of a business opportunity (Hewlett's case). Only two state statutes in the US, New York and Georgia explicitly regulate vote-buying. ${ }^{3}$

When a person purchases stock or shares in a corporation, he/she does not own the property of the corporation, but only the ownership of the stock or shares. By virtue of this ownership however, the stockholder ${ }^{4}$ has more than a contractual relationship with the corpora- tion. They have what the law regards as a "chose in action" or proprietary interest in the stock which distinguishes them from normal creditors or debenture-holders whose rights are only defined by the contract formed with the corporation. This proprietary interest in the stock confers upon the stockholder an "exclusive title" (Colten v. Jacques Marchais, Inc.) or "control" to the exercise of a set of rights and neither the corporation nor anyone else can interfere with their exercise. These rights include rights to dividends, financial rights on dissolution of the corporation, voting rights, conversion or redemption rights for existing shares, or preemptive rights to purchase newly issued shares. Voting rights, usually in proportion to the number of shares possessed unless otherwise provided for in the company's articles, include the right to vote on governance matters such as director elections or the approval of significant corporate transactions such as amendment of the company's articles, the creation of new classes of stock, mergers and acquisitions, or sales of all the corporation's assets (Palmiter, 2003).

Since voting is a proprietary interest, shareholders have full discretion as to how and whether they want to use their voting rights, subject to certain legal restrictions intended to prevent abuse by controlling shareholders. In the absence of fraud, shareholders can legally choose whether to separate their ownership and control over the shares, such that they can continue to enjoy the economic benefits of owning the shares although they have chosen to give up control over the voting rights attached to the shares.

\section{Ways of transferring voting rights}

The practice of divorcing ownership and control of shares has a long tradition in US corporate history. As early as the 1890s, corporate lawyers devised the technique of using a voting trust in which shareholders transfer their shares to a trustee who acquires the exclusive power over the voting rights, while all other rights of ownership remain with the trust beneficiaries. Courts in the early days were not very receptive to the idea of separation of voting and ownership (Shepaug Voting Trust Cases; White v. Thomas Inflatable Tire Co.). Today, however, virtually all state statutes allow the use of voting trusts, subject to certain requirements. Trust documents are kept in the corporation's main office and are open for inspection. Voting trusts have a specific term of usually ten years, and the title of the shares is actually transferred to the trustee. The trustee also attracts the general fiduciary duties imposed by the law. 
A simpler form of voting coalition is the forming of a vote pooling agreement between shareholders whereby the parties involved agree that they will vote unanimously on a subject matter. As there is no actual separation of ownership and control of the shares in this case, the courts were more tolerant towards vote pooling agreements (Ringling v. Ringling Bros.-Barnum \& Bailey Combined Shows). Such agreements can be legally enforced, which means that should one of the parties decide to back out and not comply with the terms of the agreement, they can be compelled by the court to continue their obligation rather than simply to pay the plaintiff monetary damages.

Another type of agreement is irrevocable proxies, whereby the parties give another person (or each other) binding authority to vote their shares. For the irrevocable proxies to be legally valid, most corporate statues generally require them to be "coupled with an interest" so that the proxy holder can align their own interest with that of the shareholderprincipal. Examples of valid interest include options to buy the stock; lending money to the shareholder who pledges the stock as collateral; or having an economic interest in the corporation.

Unlike these types of voting agreements that are seen as more genuine ways for stockholders to overcome collective action problems however, vote-buying per se is controversial. This is partly because of its arguably unethical nature in the political arena, where the right to elect a representative body to govern the state should not be separated from the status of citizenship in that state. We will not repeat at length the main arguments against political vote-buying (which include that such practice is against equality, efficiency and inalienability) since they have been addressed in detail elsewhere. However, as Hasen notes, there is a difference between political and corporate vote-buying (Hasen, 2000). While the equality and inalienability values in political systems embraced by many developed nations do not allow "wealth [to] prevail where it should not" (Levmore, 1996) by permitting the poor to sell their votes in a political election, the same considerations do not underlie corporate vote-buying.

A business corporation is "organized and carried on primarily for the profit of the stockholders" (Dodge v. Ford Motor Co.) and as long as shareholder democracy is preserved (in the sense that stockholders are allowed to make a choice on whether it is more profitable to them to sell off or keep their stock and the associated rights), the law permits them to consider their narrow economic self-interest in casting votes in corporate elections. They are not obliged to consider the interests of other shareholders in such elections. This is the same position in the US (Schreiber's case) as well as in the UK. ${ }^{5}$

A stronger objection against corporate votebuying is its use by the management to push through transactions that might face shareholder opposition, for example in mergers and acquisitions. Corporate assets are often used to purchase the votes, and preferential treatment may be given to some shareholders, for instance, purchasing of the stock at a premium over the market price (Good v. Texaco, Inc.) or granting of a loan on terms not available to other shareholders. Perhaps inevitably, votebuying agreements can attract charges of conflict of interest and allegations of board entrenchment. However, as shown from the judgement in Schreiber's case and other cases that follow, vote-buying can be carried out legally, and as we will explain later, it can be a useful and legitimate strategic tool.

\section{Legal position in the UK on the transferring of voting rights}

There has been no reported case in England directly concerning corporate vote-buying. To understand how English law would view such a practice, the issue can be analysed on two levels. First, how does English law consider voting agreements, if they provide for a pecuniary benefit to a particular shareholder for voting in a particular way? Second, how far would English law allow a board to engage in vote-buying practice by using corporate assets as considerations?

English law is not adverse to the idea of members of a company entering into a contract requiring that they vote their shares in a particular way on certain defined matters and resolutions. In fact, shareholder agreements are often used to supplement the articles and are especially important in entrenching individual member's rights. In Russell v. Northern Bank Development Corpn Ltd, the House of Lords on an appeal from the Court of Appeal in Northern Ireland held that an agreement between four shareholders of a private company not to vote in favour of an increase in share capital unless they had agreed this in writing was valid. On the other hand, voting trusts are not very common in the UK and traditionally they are used to settle shares with trustees as part of a settlement rather than as a device for controlling corporate power.

Although shareholder agreements binding shareholders inter se supported by mutual promises are enforceable, views are divided as to whether their validity may be impaired if they provide for a pecuniary benefit to a par- 
ticular shareholder for voting in a particular way. ${ }^{6}$ Finn has argued that such agreements are illegal on grounds of public policy and on the basis that they amount to bribes or that they constitute a fraud on the other shareholders (Finn, 1978). However, Farrar and Hannigan have argued that the reasoning against contracting out of the winding-up scheme and against fraud on creditors should not be used in situations concerning shareholder agreements (Farrar and Hannigan, 1998). They see no basis why the mere passing of a money consideration should invalidate such agreements, since it has been held that a shareholder is entitled to consider their own interest without regard to the interest of other shareholders in the exercise of their votes (Coronation Syndicate Ltd v. Lilienfeld and New Fortuna Co. $L t d)$.

Our view is that the rationale that votebuying should be illegal per se based on the theory of trust amongst shareholders is outmoded in view of the evolving corporate environment where modern corporations are generally characterised by widely scattered shareholders. It has already been said many times by the courts ${ }^{7}$ that as long as the company is solvent, the shareholders are essentially the company and owe no fiduciary duty to the company or to their fellow shareholders. Every shareholder has "a perfect right to vote upon any such question although he may have a personal interest in the subjectmatter opposed to, or different from, the general or particular interests of the company". ${ }^{8}$ Therefore, subject to the rules relating to unfair prejudice, there is no legal ground for restricting how a shareholder should deal with their voting power.

Should the position change if the purchase party is not a shareholder themselves? If voting rights are considered as proprietary interests, then the shareholders can sell their voting rights to whoever they wish to. The freedom to deal with one's own property is the epitome of a proprietary interest. In summary, there should be no reason why a shareholder cannot enter into an enforceable contract with a third party for a consideration personal to the shareholder to vote in a manner dictated by the third party under English law.

\section{Vote-buying by corporate boards in the UK}

The next issue is more complex. What if the purchaser of the votes is the board of the company, and corporate assets are used as consideration? As demonstrated by US cases, corporate vote-buying by directors can be an important and useful tool in corporate planning and restructuring. In Schreiber's case, for example, all parties conceded that the purpose of the merger was beneficial to Texas International. It was also not doubted that Jet Capital had legitimate goals in opposing the merger because of the intolerable income tax burden on it. Therefore, allowing Texas International to make a loan to Jet Capital in exchange for the latter's withdrawal of its opposition to the proposed merger was crucial for furthering the interest of all Texas International shareholders. Further, in Good, the court found on the facts before it that the personal investment goals of the Bass Brothers were affecting the long-range business policies of Texaco and that the directors' decision to enter into an agreement with the Bass Brothers, which included a vote-buying condition, was to ensure that the latter would not use their stock position to the possible detriment of Texaco.

On the other hand, it also cannot be denied that a board-supported vote-buying programme runs the risks of being abused by management. Unlike US law which takes a board-centric position with its business judgement rule, English law has a more stringent standard with respect to directors' fiduciary duties. English courts are likely to look into two issues: the purpose of the underlying transaction in connection with the vote-buying scheme, and whether approval has been obtained from a disinterested majority at a shareholders' meeting where full and complete disclosure has been made.

With respect to the first issue, US courts will not strike down a corporate vote-buying agreement as long as they are satisfied that the contested transaction is intrinsically fair and its object or purpose is not to defraud or disenfranchise shareholders. However, English law takes a step further. Directors' fiduciary duties require the directors to act in what they consider to be the best interests of the company and exercise their fiduciary powers for a proper purpose. Good faith and genuine honesty in the interests of the company are not enough. ${ }^{9}$ In line with the decision of the Privy Council in Howard Smith Ltd v. Ampol Petroleum $L t d^{10}$ if the directors, when exercising a power vested in them have more than one purpose in mind, the substantial purpose for which the power was exercised must be one that is proper. Therefore, in a situation like Schreiber's case, the main purpose of the loan to Jet Capital was to secure the success of a restructuring exercise that was beneficial to the company, although it carried with it the incidental consequence that the transaction allowed Jet Capital to obtain funding which it would not have been able to secure elsewhere. 
The key point highlighted in this case was that Jet Capital was not adverse to the restructuring plan and thus the actions taken by the board only assisted the party to overcome the technical obstacle that was standing in the way of voting in favour of the proposal, which was supported by the majority of the remaining shareholders. The exercise of power by the directors in this case could not be said to be for an improper purpose.

However, cases such as Weinberger and Good could fall the other way if they were decided by English courts. In both cases, though bad faith on the part of the board was not alleged, the use of corporate assets to silence particular shareholders as long as they continued to hold the company's stock (as in Weinberger's case) or to ensure that certain shareholders vote their shares in accordance with the recommendation of the board for a period of ten years (as in Good's case) are unlikely to be considered as proper use of power under English law. Many English cases have held that attempts by directors to consolidate their control or prevent a rival body from taking over the company were invalid, notwithstanding the asserted belief of the directors that they were acting in the best interests of the company.

In the recent Court of Appeal case of Criterion Properties v. Straford UK Properties, the court was asked to rule on a "poison pill" arrangement which aimed to protect a party in a joint venture against a possible take-over and change of management. The scope of the arrangement between Straford UK Properties LLC (Oaktree), an American company, and Criterion Properties plc (Criterion), a UK plc, was very wide as it allowed the interest of Oaktree in the joint venture to be bought out on very favourable terms in the event of another party gaining control of Criterion or in the event of the existing Chairman or managing director of Criterion ceasing to be director or employee or involved in the management of Criterion. The court was prepared to proceed with the case on the basis that the arrangement was made in good faith, for good commercial reasons and that the parties had no reason to believe that it was in any way improper. However, Brooke and Carnwath LJJ held that even if English law, following some rulings in other common law jurisdictions, were to accept that it was permissible for the board to enter into transactions in order to deter a takeover which would cause serious economic harm to the company, the present arrangement went "far beyond anything which could be justified for the purpose of deterring an unwelcome predator". The buy-back provision could be triggered by any takeover, not only by a hostile predator, but even by one regarded as wholly beneficial to Oaktree or even Oaktree itself. It could also be triggered by the departure of the named persons, even in circumstances which had nothing to do with a change of control, for example death or dismissal due to misconduct. Therefore, the court did not think that the agreement concerned could be justified as a reasonable exercise of the directors' power in the interests of the company. By the same reasoning, it is difficult to see how the blanket control over the voting rights given to the board in Weinberger's case and Good's case can be justified as reasonable, even if it was ostensibly not done to perpetuate the directors themselves.

However, even if it is decided that the directors have used their powers for an improper purpose, the transaction, being voidable, can still be saved after ratification by the general meeting (Bamford v. Bamford). In any case, it is submitted that all transactions involving corporate vote-buying should be put before the general meeting for approval to avoid any allegation of management self-entrenchment. In fact, the protective measures advocated in Schreiber's case are worth consideration by corporate boards thinking of engaging in votebuying (i.e. the forming of a special committee with independent counsel to advice on the vote-buying agreement and its related deals, putting the agreements before a full board, and the proposal should be separately voted by the disinterested shareholders before it is entered into by the board on behalf of the company).

\section{Strategic reasons for corporate vote-buying}

This section draws from US legal cases to illustrate legitimate strategic reasons for employing corporate vote-buying. In spite of some initial resistance, courts in the US gave the green light to corporate vote-buying in 1982 in the landmark Delaware case of Schreiber $v$. Carney. As can be seen from the judgement of Hartnett, J., the courts look at the reasons behind the vote-buying rather than the act itself, to determine its legality. The main concern is whether the object or purpose of the vote-buying is to "defraud or in some manner disenfranchise the other stockholders" and if the answer is negative, then the vote-buying is deemed to be legal.

In Schreiber's case, Jet Capital Corporation, a large share and warrant-holder of Texas International Airlines, opposed a proposed restructuring exercise of the airline, as Jet Capital would be faced with a substantial tax liability should the deal go through. The restructuring 
exercise would have required Jet Capital to convert its existing warrants to Texas International's stock prematurely before the due date for conversion. However, Jet Capital lacked the approximately three million dollars necessary to exercise the warrants. The only alternative available to Jet Capital was for it to participate in the restructuring exercise and exchange its Texas International warrants for Texas Air warrants (Texas Air was a holding company formed to effect the re-organisation). However, the Internal Revenue Service had ruled that Jet Capital would have to pay US\$800,000 in federal income tax liability since it would be deemed to have realisable taxable income from the merger as if the warrants had been exercised. Therefore, Jet Capital, as a public company accountable to its own shareholders, decided to oppose the merger. In the end, the Texas International Airlines board agreed to loan Jet Capital sufficient capital to fund an early exercise of the warrants, in return for Jet's voting support for the restructuring.

In this case, it was clear that both the board of Jet Capital and that of Texas International Airlines were acting in the interest of their respective companies, even though their interests might be on opposing ends. Therefore, to allow the board of Texas International the power to grant a loan to Jet Capital in exchange for its support in the restructuring exercise would have been in favour of everyone concerned. In other cases, boards have entered into vote-buying agreements with greenmailers $^{11}$ or dissident shareholders (Weinberger $v$. Bankston) using corporate funds so as to get them off their backs, or to persuade them to refrain from proxy activities and behave as silent shareholders for the wellbeing of the firms rather than for the purpose of entrenchment of the boards.

For instance, in Good v. Texaco, Inc., the board of one of the largest petroleum companies, Texaco Inc., was involved in a hotly contested takeover battle with one of its competitors, Pennzoil Corporation, to acquire the Getty Oil Company. An investment group controlled by the Bass family ("Bass Brothers") saw a chance to "loot" Texaco and increased its stake in Texaco from less than 5 per cent to 9.9 per cent. The Bass Brothers threatened to further increase their Texaco stake and to join forces with competitor Pennzoil so as to foil the takeover plan of Getty. After some bargaining, Texaco eventually agreed to repurchase Texaco stock held by the Bass Brothers at the price of US $\$ 50$ per share (down from the initial price of US\$68 per share sought by the Bass Brothers); at this time the market price for Texaco shares was $\$ 48-3 / 8$ per share. Under the terms of the repurchase agreement, the Bass Brothers received payment of approximately one-half of the purchase price in cash and the remainder in the form of a new issue of preferred stock with voting rights in Texaco. However, to prevent the Bass Brothers from using their voting power to once again illicitly disrupt management's corporate plans and policies, the board asked the Bass Brothers to agree to vote their preferred shares in accordance with the wishes of the Texaco board of directors (to which they agreed). Some shareholders of Texaco were unhappy with this special arrangement however, and sought to invalidate the share repurchase agreement on the grounds that it served no legitimate corporate purpose of Texaco, and that it was amounted to an illegal vote-buying scheme. In the end, the court ruled in favour of management.

The court noted that the vote-buying agreement was not void per se and its purpose must be examined to determine its legality. The court was satisfied that the board had a majority of independent directors:

Of Texaco's thirteen directors ten were outsiders who held no employment positions with the company. These directors are all apparently well-to-do in their own right and they would not appear to be dependent in any way on the fees paid to them for serving as directors even though such compensation might seem substantial to the average layman.

Therefore, the plaintiff could not prove that the decision of the Texaco directors to repurchase the Bass Brothers' shares was motivated by their selfish desire to protect their positions on the board. In addition, the court noted that the Bass Brothers were "shrewd businessmen" motivated for "their own economic reasons" who chose to cause disruption to the company at a time when the company was involved in a hostile tender offer. Also, the board sought advice from its investment banker and its two law firms who unanimously recommended a prompt repurchase of the shares as it would be in the best interests of Texaco to do so. Finally, it was proven on the evidence that the Bass Brothers agreed to vote the preferred shares as directed by the Texaco board in order to bring about a satisfactory accommodation to both sides (i.e. marketability and tax advantages to the Bass Brothers versus the assurance sought by the board that the Bass Brothers would not use their stock position to the possible detriment of Texaco and its long-range business policies in the process of furthering their personal investment goals). This, as the court said, would throw out any argument that the motivation of the Texaco board was to purchase the 
shares in order to secure their continued control of corporate affairs.

Similarly, in Weinberger v. Bankston, two shareholders (Bertoglio and Ling) of Texas International Company, who had earlier wanted to acquire TI but failed, decided to try and liquidate the company through a proxy vote. The proxy effort was unsuccessful, however. Thereafter, Bertoglio and Ling announced that they would again mount a proxy effort to gain seats on the board of directors and file a suit alleging proxy violations by TI. Desperate to get Bertoglio and Ling off their backs, the board of TI entered into a settlement agreement with them, whereby the company would pay for Bertoglio and Ling's proxy expenses in return for their promise to refrain from proxy activities and remain as silent shareholders. This agreement prompted one minority shareholder to file a derivative action, contending that the agreement was an improper use of corporate assets and helped to entrench the management and directors. The court ruled however that management had broad discretion in entering into settlement agreements and that the plaintiff had not sufficiently rebutted the claim by management that TI benefited from the settlement.

Thus in the Schreiber case, the management of Texas International Airlines engaged in the buying of Jet Capital's voting rights, so that it would have sufficient shareholder support to engage in a restructuring exercise considered crucial for its future. Jet Capital's initial opposition in this case had not been based on any unfavourable strategic evaluation of the restructuring, but on the fact that Jet would be faced with a huge tax bill that would hurt their own shareholders; arguably a good reason for opposing.

In the Texaco case, the company bought control of the Bass Brothers' voting rights so that the Brothers could not illicitly use these rights to again blackmail the company with threats to foil legitimate strategic actions. Lastly, in the Weinberger case, management sought to control the voting rights of dissident shareholders Bertoglio and Ling, so as to foil any further efforts to liquidate the company, or to gain seats on the board and start arguably frivolous legal proceedings against the company. What all these cases have in common is the buying of corporate voting rights by management, for legitimate purposes of strategic importance to the company.

\section{Negotiating the minefields of corporate vote-buying}

What are the key principles that directors can keep in mind with regard to vote-buying?
How can directors pro-actively avoid having to deal with all the legal liabilities that can arise from vote-buying activity? There are four principles involved.

\section{Vote-buying is not illegal}

Despite initial legal ambiguity, it is now clear that vote-buying agreements are not illegal per se (for instance, see cases like Schreiber and Hewlett). This means that courts will not declare a transaction void, even if the plaintiff proves the existence of a vote-buying agreement, and even if the company management has bought votes using corporate assets. For example, in the cases of Schreiber and Good, the courts upheld the decisions in favour of management and did not invalidate the transactions involving vote-buying.

However, that does not mean that all votebuying arrangements are valid. They can still be viewed with suspicion, and are voidable. If a plaintiff is able to prove the existence of votebuying, the defendant will not be able to apply for a dismissal of their claim and the case will proceed to trial. At the trial, the plaintiff still has the burden to prove that the transaction is beyond one which is legally acceptable (Hewlett's case).

\section{Vote-buying and related transactions are protected by the business judgement rule}

Modern day courts have taken a rather liberal approach towards management-initiated votebuying claims. Based on the cases decided after the landmark 1982 Schreiber's case, boards are still protected by the business judgement rule when it comes to allegations of illegal vote-buying. The business judgement rule is one of the cornerstones of US corporation law. It expresses a judicial "hands off" philosophy when a business decision is being challenged. A full discussion of the operation, rationale and remedies of this rule is out of the scope of this paper. In essence however, the business judgement rule is a rebuttable presumption that directors in performing their functions are honest and well-meaning, and that their decisions are informed and rationally undertaken (Palmiter, 2003). Therefore, the business judgement rule presumes directors do not breach their duty of care, unless the claimant is able to prove that there was fraud, illegality or a conflict of interest (e.g. the directors directly benefited from the underlying transaction), the lack of a rational business purpose, or gross negligence in discharging duties to supervise and to become informed. Where the 
business judgement rule applies, the onus is on the plaintiff to prove otherwise.

Therefore, in the Schreiber's case, once it was conceded that the purpose of the underlying management-endorsed merger was, in the words of Judge Hartnett, to "enable the corporation, Texas International - under a new corporate structure - to diversify, to strengthen itself financially and in general to be transformed into a more viable and aggressive enterprise", the court will not assume bad faith on the part of the directors even though corporate assets were used to buy stockholders' votes and push through the merger.

Similarly, in the Good's case, the court, citing Delaware case precedents, stated that a decision by a board of directors to use corporate funds to repurchase shares from a dissident shareholder in order to eliminate what appears to be a clear threat to the best interests of the corporation is a decision protected by the business judgement rule; and one which can be overcome only by a conclusive showing of fraud or other misconduct. Even though this has not been tested elsewhere, it is likely that courts in other US jurisdictions will hold a similar view.

\section{Management should ensure that the purpose of the transaction does not defraud or disenfranchise any group of shareholders}

This is a crucial element that courts will consider regarding the legality or otherwise of a vote-buying transaction. Even though stockholders' voting rights are proprietary and they can do what they wish with them, courts will closely scrutinise vote-buying for cases where "a shareholder who divorces property interest from voting interest, fails to serve the "community of interest' among all shareholders, since the 'bought' shareholder votes may not reflect rational, economic self-interest arguably common to all shareholders" (In re IXC Communications, Inc. Shareholders Litigation v. Cincinnati Bell, Inc.).

In the case of Macht v. Merchants Mortgage $\mathcal{E}$ Credit Company, the court struck down the vote-buying agreements instigated by a director cum shareholder who was scheming to wrest control of the corporation from the other stockholders for fraudulent motives, such as to move the assets from this corporation to another corporation formed by him.

In the Hewlett case, the plaintiff was not able to prove his claim that the HP management improperly coerced Deutsche Bank to switch its vote and support the merger, knowing that Deutsche Bank's votes would tip the balance of the shareholder vote, using as a carrot the promise of "future business". If this claim was proven, then buying the Deutsche Bank votes would have been an improper use of corporate assets by the HP board. In the end, the court was not convinced that this was the case and concluded that the bank's eventual vote in support of the merger was based upon the harm the bank believed might incur if the merger was not approved, rather than on the promise of future business from the corporation.

Alternatively, if the management is able to show that despite the vote-buying agreement with specific shareholders, the outcome of the vote would have been the same, then the plaintiff cannot prove that other shareholders have been disenfranchised by the action. This was the case in In re IXC Communications' case. In this case, although the plaintiff could prove that there was indeed a vote-buying agreement between a prospective target company and a particular shareholder, it was accepted by the court that the independent majority of shareholders could still freely vote for or against the merger, based on their own perceived best interest. Therefore shareholders were not "locked up" by the vote-buying arrangement.

\section{Management should build into the transaction protective measures to safeguard against oppression of shareholders' rights}

Such protective measures would include for example the forming of a special committee with independent counsel to advise on the vote-buying agreement and related deals, and putting the agreements before a full board. In addition, the vote-buying proposal should be separately voted on by the shareholders before it is entered into by the board on behalf of the corporation. As a condition for passage of the vote-buying proposal, a majority of outstanding shares (as well as a majority of the shares neither participating in the agreement nor owned by directors and officers of the corporation) have to be voted in favour of the proposal. According to the Schreiber's case, all these will safeguard against future litigation, as they will ensure that there is "a full disclosure of all germane facts with complete candor [and will] preclude any further judicial inquiry".

Another consideration that makes such protective measures important, is that, unlike a vote-pooling agreement (Soloman and Palmiter, 1999), vote-buying agreements do not have to be in writing to be valid. A plaintiff 
does not have to establish that there was a contractually binding obligation between parties to an agreement to vote shares in a particular manner. It is enough if a plaintiff can show facts from which it can be inferred that stockholders have voted as directed by another party in return for some consideration paid to them.

Having said that, however, each case will still be examined by courts on its own merits to determine whether any shareholder group has been oppressed or disenfranchised; and courts may still validate vote-buying agreements that do not exhibit all the above protective measures, as the judge in the Hewlett case held.

\section{Conclusion}

In this paper we suggested that there is a fine line between legitimate use of vote-buying for strategic reasons that place the best interests of shareholders at centre stage, and its negative connotations as a potential instrument of fraud that could disfranchise shareholders on the other hand. We examined the legal history of corporate vote-buying and the rationale for the courts' vigilance on this practice, in both the United States and the United Kingdom. We then examined several legal cases involving vote-buying and outlined some legitimate reasons for this practice, such as gathering shareholder support for strategic actions that are deemed crucial for the future of the company, or persuading dissident shareholders to refrain from blackmailing the company with the threat of mounting arguably frivolous legal proceedings against it. We finally discussed key principles that a board of directors should bear in mind when engaging in corporate vote-buying, so that it can employ the practice productively and legitimately, keeping in mind shareholders' best interests and avoiding potentially costly and destructive legal challenges. These included the imperative that directors bear in mind the business judgement rule when contemplating this practice, taking decisions based on what would be best for the company and its shareholders; ensuring that any vote-buying agreement does not defraud or disenfranchise any group of shareholders; and building into the transactions involved protective measures that safeguard against oppression of shareholders' rights

Hewlett's case will not be the last time corporate vote-buying will be challenged in court. Legal history shows, however, that courts have been tolerant towards management in legal judgements. Business history shows, in addition, that there can be legitimate, strategic reasons for management to buy control of voting rights of certain shareholders. However, management still faces a high threat of litigation if vote-buying is involved, so vigilance in dealings involving such transactions is a must.

\section{Acknowledgement}

This paper is a substantially lengthened and reworked version of Lan and Heracleous (2005).

\section{Notes}

1. Judge Chancellor William Chandler, Hewlett v. Hewlett-Packard Co. (2002 Del. Ch. Lexis 44 (Del. Ch. Apr. 8, 2002); 2002 Del. Ch. Lexis 35 (Del. Ch. Apr. 30, 2002).

2. The claim was brought under Del. Code Ann. tit. 8 (1899), §225(b) which provides that "upon application of any stockholder or any member of a corporation without capital stock, the Court of Chancery may hear and determine the result of any vote of stockholders or members, as the case may be, upon matters other than the election of directors, officers or members of the governing body. Service of the application upon the registered agent of the corporation shall be deemed to be service upon the corporation, and no other party need be joined in order for the Court to adjudicate the result of the vote. The Court may make such order respecting notice of the application as it deems proper under the circumstance".

3. NY CLS Bus Corp § 609(e) (2003); O.C.G.A. § 7-1 - 437(f) (2002).

4. Although there are technical differences between the terms "stockholder" and "shareholder" which are beyond the scope of this paper, the two terms will be used interchangeably throughout this paper to mean a legal holder of the stock or shares in a corporation.

5. It has been repeatedly laid down in many English cases that votes are proprietary rights which the holder may exercise in his own selfish interest even if these are opposed to those of the company or other shareholders, see North-West Transportation Co v. Beatty (1887) 12 App. Cas. 589, Burland v. Earle [1902] AC 83; Goodfellow v. Nelson Line [1912] 2 Ch. 324.

6. Compare the views of Finn (1978) Shareholder Agreements, ABLR 97 with those of Farrar and Hannigan (1998).

7. For instance, the Court of Appeal in Multinational Gas and Petrochemical Co. v. Multinational Gas and Petrochemical Services Ltd and others, [1983] 2 Ch. 258, [1983] 2 All ER 563, [1983] 3 WLR 492, [1983] BCLC 461; the Privy Council in North-West Transportation Co. Ltd v. Beatty (1887) 12 App. Cas. 589.

8. Per Sir Richard Baggallay in North-West Transportation Co. Ltd v. Beatty (1887) 12 App. Cas. 589 at 593. 
9. Punt v. Symons \& Co. Ltd [1903] 2 Ch. 506; Hogg v. Cramphorn Ltd [1967 Ch. 254; Howard Smith Ltd v. Ampol Petroleum Ltd [1974] AC 821; Lee Panavision Ltd v. Lee Lighting Ltd [1992] BCLC 22; Criterion Properties plc v. Stratford UK Properties LLC [2003] 2 BCLC 129.

10. This case has been endorsed by the House of Lords in Equitable Life Assurance Society $v$. Hyman [2002] AC.

11. The term "greenmail" has been defined as "the accumulation of a significant amount of stock by a shareholder, or group of shareholders acting in concert, for the purpose of intimidating a board of directors into causing the corporation to repurchase such shares at a substantial premium over their realistic market price." Good v. Texaco, Inc., Del. Ch., C.A. No. 7501, 1985 Del. Ch. LEXIS 445, *25-26, Brown, C. (Feb. 19, 1985).

\section{References}

Farrar, J. and Hannigan, B. (1998) Farrar's Company Law, 4th edn. London: Butterworths.

Finn, P. (1978) Shareholder Agreements, Australian Business Law Review, 6, 97.

Hasen, R. (2000) Vote Buying, California Law Review, 88, 1323-1371.

Lan, L. and Heracleous, L. (2005) Shareholder Votes for Sale, Harvard Business Review, 20-24.

Levmore, S. (1996) Precommitment Politics, Virginia Law Review, 82 (4), 567-627.

Palmiter, A. (2003) Corporations: Examples E Explanations, 4th edn. New York: Aspen Law \& Business.

Soloman, L. and Palmiter, A. (1999) Corporations: Examples \& Explanations, 3rd edn. New York: Aspen Law \& Business.

\section{List of cases cited in the text}

Bamford v. Bamford [1970] Ch 212.

Colten v. Jacques Marchais, Inc., 61 N.Y.S.2d 269,

271 (N.Y. 1946).

Coronation Syndicate Ltd v. Lilienfeld and New Fortuna Co Ltd, 1903 TS 489.

Criterion Properties v. Straford UK Properties [2003] 2 BCLC 129.

Dodge v. Ford Motor Co., 170 N. W. 668, 684 (Mich. 1919).

Good v. Texaco, Inc., Del. Ch., C.A. No. 7501, 1985 Del. Ch. LEXIS 445.
Howard Smith Ltd v. Ampol Petroleum Ltd [1974] AC 821.

In re IXC Communications, Inc. Shareholders Litigation v. Cincinnati Bell, Inc., 1999 Del. Ch. LEXIS 210, *21.

Kass v. Eastern Airlines, No. 8700 (Del. Ch. 1986).

Macht v. Merchants Mortgage E Credit Company, 22 Del. Ch. 74, 194 A. 19 (1937).

Ringling v. Ringling Bros.-Barnum \& Bailey Combined Shows, 29 Del. Ch. 318 (Del. Ch. 1946).

Russell v. Northern Bank Development Corpn Ltd [1992] BCLC 1016.

Schreiber v. Carney, 447 A.2d 17 (Del. Ch. 1982). Shepaug Voting Trust Cases, 60 Conn. 553 (Conn. 1890).

Weinberger v. Bankston, 1987 Del. Ch. LEXIS 514; Fed. Sec. L. Rep. (CCH) P93, 539.

White v. Thomas Inflatable Tire Co., 52 N.J. Eq. 178 (N.J. 1893).

Luh Luh Lan is an Assistant Professor of Law at NUS Business School, National University of Singapore. She has written chapters for law and management books and published papers in the areas of company law, corporate finance, corporate governance and advertising and marketing law. Some of the leading journals where her works have been published include Journal of Business Law, Singapore Journal of Legal Studies, International Company and Commercial Law Review, Harvard Business Review and Journal of Public Policy and Marketing.

Loizos Heracleous is Professor of Strategy at Warwick Business School and Associate Fellow of Templeton College Oxford. He is the author or co-author of four books and over 45 published papers in the areas of strategy and organisation, corporate governance, organisational discourse and organisation change and development. His research has received three awards from the US Academy of Management and has been published in several leading journals, including the Academy of Management Journal, Human Relations, Journal of Management Studies, Journal of Applied Behavioural Science, Harvard Business Review and MIT Sloan Management Review. 